\title{
Supporting Finnish Language Learners in Basic Education: Teachers' Views
}

\author{
Raisa Harju-Autti \\ Tampere University \\ Finland
Hanna-Maija Sinkkonen
University of Turku
Finland

\begin{abstract}
This paper sheds light on linguistic support concerning the language of schooling in multilingual classrooms in Finnish lower secondary education. We ask how the teachers consider knowing their students, what the needs in linguistic and academic support are, and how the needs are met. The data were collected from teachers in eight lower secondary schools in different parts of Finland. The findings show that the means to scaffold Finnish language learners are still in the development phase as there are no uniform ways to support students with an immigrant background in Finnish basic education.
\end{abstract}

KEYWORDS: multilingualism, linguistic support, scaffolding, Finnish basic education, immigrant students

\author{
Finnish Basic Education and Immigrant Students \\ Theoretical Framework \\ Methodology and Data \\ Results \\ Discussion and Conclusions \\ Practical Implications \\ References \\ Author Contact
}

\begin{abstract}
Although Finland has been a country experiencing both emigration and immigration for centuries, only from the beginning of the 1990s has the number of people with an immigrant background rapidly grown (Martikainen, 2013). Due to the increasing cultural and linguistic diversity in Finnish society, the school system in Finland is facing new challenges. The low academic performance of minority or immigrant students is a stable phenomenon in many Western countries as well as in Finland (Hachfeld, Anders, Schroeder, Stanat, \& Kunter, 2010; Organisation for Economic Co-operation and Development [OECD], 2015). Furthermore, Finland has been referred to as the Miracle of Education (Niemi, Toom, \& Kallioniemi, 2012), but the Programme for International Student Assessment (PISA) results for
\end{abstract}


2012 and 2015 indicate that Finland can no longer rely on its previous results in learning (OECD, 2015; Vettenranta et al., 2016). On average, immigrant students perform less well in school compared to native students in Finland than do immigrant students in other countries (Harju-Luukkainen et al., 2014; NAOF, 2015). The PISA 2015 results seem to confirm this trend, although the number of immigrant students participating in the tests is limited (Vettenranta et al., 2016). However, immigrant students are not the only group performing less well in schools, this phenomenon is also met among students who live in foster care (Heino \& Oranen, 2012).

In 2015, Finland was one of the countries in Northern Europe to receive a record number of asylum seekers (OECD, 2015). In addition to that, migrant flows have increased during the latest decades: People move to Finland for several reasons, such as family relations, work, or studies (see Martikainen, 2013). Most of the migrants come from Eastern Europe, but especially after 2015 the number of immigrants from the Middle East and Northern Africa has risen (Statistics Finland, 2019a). The most spoken foreign languages (i. e., other than Finnish, Swedish, or Sami) are Russian, Estonian, Arabic, and Somali, but there are dozens of other foreign languages spoken in Finland as well (see Statistics Finland, 2019b). This new-scale intensification of cultural diversity in society with more heterogeneous groups (e.g., Civitillo et al., 2017; Gutentag, Horenczyk, \& Tatar, 2017; OECD, 2015) requires teaching methods that meet the needs of linguistically and culturally rich classrooms. It also requires attention to be paid to the fact that the newly arrived students come from a variety of backgrounds, and their reasons for moving to Finland are also very different. The need for specific linguistic support for adolescents arriving in Finland is undisputed: Language is the key to learning (Harju-Autti, Aine, Räihä, \& Sinkkonen, 2018; Sinkkonen \& Kyttälä, 2014). Over 80 percent of the first-generation immigrant students in Finland do not speak the language of instruction at home (OECD, 2015).

The aim of this survey is to provide information on the current situation in lower secondary schools in Finland, especially in regard to multilingualism and ways of supporting the Finnish language learners (FLLs), who in this present study are defined as students who have lived in Finland for less than five years. The research questions are:

1. What do the teachers report concerning the FLLs' linguistic and academic skills?

2. How do teachers describe the needs for support among FLLs in basic education?

3. In what ways is the support organized? 


\section{Finnish Basic Education and Immigrant Students}

Basic education and lower secondary education in Finland are divided into four different levels: pre-primary education at the age of six, primary level education from the age of seven to twelve (grades 1 to 6 ), lower secondary level education from the age 13 to 16 (grades 7 to 9), and general or vocational upper secondary level education (grades 10 to 12). In primary school, teaching in almost all the subjects is conducted by primary school teachers who have a master's degree in educational sciences. From lower secondary level onwards, the subjects are taught by specific subject teachers who are specialized in particular subjects, having pedagogical studies as a minor subject (60 ECTS, European Credit Transfer and Accumulation System) in their master's degree (Finlex, 1998). On the primary level, students spend approximately 20 hours per week with their class teacher, and there is time for forming a pedagogical relationship. This study focuses on the lower secondary level, where the subjects are taught by subject teachers whom the students meet only for a couple of lessons in the week, depending on the subject. Class supervision on a more administrative level is carried out by subject teachers as homeroom teachers (see for example City of Helsinki, 2019; Ministry of Culture and Education, 2019).

Basic education from pre-primary school until the end of lower secondary school is free for all children in Finland. Because Finland is a bilingual country, basic education is provided in Finnish or in Swedish, which are the two official languages (Basic Education Act 628/1998, 1998). In Finnish basic education, the newly arrived students can be provided with a year of preparatory studies (Finnish National Agency for Education [FNAE], 2019a). However, offering the preparatory studies is not mandatory for the municipalities (FNAE, 2015a). Preparatory education aims at providing students with the basic skills in the language of schooling (i.e., Finnish or Swedish), as well as in the Finnish academic school culture (FNAE, 2015b). After approximately a year in preparatory education, students are placed in regular classes, and the support they are given there depends on decisions and funding based on municipal decision-making. Unfortunately, one year of preparatory education for learning in a new country may provide the FLLs with an inadequate start. Further, when attending regular classes at the primary level, the students work both with the same peers and with the same teacher until the end of the sixth grade. In that context, the teacher is able to form a coherent pedagogical relationship with FLLs, as it is possible to observe and assess the students on a daily basis. This is not the case when students attend regular classes on the lower secondary level, as subject teachers and the students only work together for a couple of lessons per week. In addition to the variety of teachers, the groups of students vary because there are differences in the optional courses the students take. Furthermore, the teachers on the lower secondary level are used to teaching students with similar backgrounds: Six years of Finnish basic education has been the default setting for decades. As the number of culturally 
and linguistically diverse students has grown, and continues to grow, it is important that the teachers gain new teaching skills. However, it has been found that subject teachers use less versatile teaching methods in teaching diverse classes when compared to primary school teachers (Saloviita, 2018).

In Finnish basic education, Finnish as a second language (FSL) teaching is taught as part of the regular lesson planning for the syllabus of Finnish language and literature. Also, a variety of different mother tongues of the students are taught outside the regular lesson plan as optional studies, such as Russian, Arabic, Persian, Kurdish, etc. However, often only the most common mother tongues can be taught, and the selection of languages varies depending on the size of the multilingual population and the financial resources, as well as on the teacher capacity of each municipality (Harju-Autti et al., 2018). The government offers financial support for teaching minority languages and the students' mother tongues (Finlex, 2007). However, only teaching the FSL syllabus is mandatory-forming separate groups for Finnish language and literature and FSL is not required (FNAE, 2019b).

\section{Theoretical Framework}

The theoretical framework for this study is based on both linguistics and education, as well as on educational linguistics (van Lier, 2004; Spolsky, 2008). The main theoretical background for this study is sociocultural theory, on which the Russian psychologist L. S. Vygotsky and his colleagues based their research on sociocultural learning (Lantolf \& Thorne, 2006). More specifically, this study is based on the concept of the zone of proximal development (ZPD) (Vygotsky, 1978; 1986), which has been widely used as a theoretical framework in the context of second language acquisition (SLA) (e.g., Donato, 1994; Lantolf \& Appel, 1994; Lantolf \& Poehner, 2010; Lantolf \& Thorne, 2006; van Lier, 2004; Washburn, 1994; Zuengler \& Miller, 2006). However, SLA has mainly been studied among Englishspeaking countries, and the focus of SLA studies has been on the acquisition of English as a second language (Cenoz \& Gorter, 2019).

When discussing the ZPD (Vygotsky, 1978; 1986) in the school context, the key action is scaffolding, that is, offering the novice an encouraging and supportive environment for learning (see Kayi-Aydar, 2013; Walqui, 2006). The concept of scaffolding was introduced by Wood, Bruner, and Ross (1976) and derives from cognitive psychology and first language (L1) learning research wherein a knowledgeable partner provides the novice with suitable practicing methods and encouragement to learn the language in social interaction (e.g., Donato, 1994; van Lier, 2004).

Learning a new language is a time-taking process. According to Cummins (1981), it takes approximately one to two years to learn the basic interpersonal communication skills (BICS) in a new language, but in order to master cognitive academic language proficiency (CALP), the learning process can take up to 5-7 
years. Furthermore, the language used at school can also be divided into categories, such as basic everyday language, essential academic language, discipline-specific language, and school navigational language (Beacco et al., 2015). Language development is always an individual process, and the different aspects of proficiency cannot be considered to reflect just one unitary proficiency dimension (Baker, 2007; Cummins, 2008).

In Finland, Finnish or Swedish as a second language is taught in schools with FLLs. Several studies have been conducted within the field of teaching immigrants in Finland (e.g., Honko, 2013; Latomaa \& Suni, 2011; Suni \& Latomaa, 2012; Talib, 2002). In spite of the research conducted and the obvious need to improve the means to support FLLs, a lack of amendments on the legislative level still exists: There is a core curriculum for preparatory education (FNAE, 2015b) that is based on Finnish legislation (Basic Education Act 628/1998, 1998), but the ways of organizing preparatory education vary. Furthermore, the means to support FLLs depend on municipal decision-making, and that creates inequality in education. The structure of support varies, as there are no official guidelines.

For the first time, the term language awareness (see Carter, 2003; Denham \& Lobeck, 2010) was introduced in the Finnish Core Curriculum for Basic Education (FNAE, 2014) to refer to all teaching and school culture: What had previously been seen as the duty of language teachers, or special education teachers, should now be the responsibility of all the teachers. Traditionally, language awareness has been connected to language teaching (Carter, 2003; Breidbach, Elsner \& Young, 2011), and research concerning language awareness is often conducted within language teaching (see for example van den Broek et al., 2019). Furthermore, considering the high quality of language education in Finland (Hildén \& Kantelinen, 2012), the paradigm shift for all teachers to become "language teachers" will take time. The aim, however, is that every teacher works in a linguistically responsive manner (Alisaari et al., 2019; Lucas \& Villegas, 2013).

In countries such as the United States, Australia, New Zealand, Canada, Ireland, and the UK, the assessment of English as an additional language (EAL) learners has been discussed for decades as the number of EAL learners has increased. However, as Sinclair and Lau (2018) have pointed out, language assessment policies differ, and further research is needed in order to form fair and effective assessment policies to support equitable educational opportunities.

Finland is a country where standardized tests are not used in basic education or student assessment, nor in evaluating teacher performance (Morgan, 2016). Furthermore, the questions concerning EAL learners in the English speaking countries mentioned above do not translate to Finland with its less than five million speakers of Finnish: Learning English as a lingua franca is about gaining a tool with which to operate both locally and globally, whereas learning Finnish is only helpful in the Finnish context.

The need for scaffolding multilingual students' linguistic skills is widely recognized, but the means to provide adequate support have not been taken into use, and linguistic approaches have not been systematically used in intercultural 
education and classrooms (Dervin \& Liddicoat, 2013; Latomaa \& Suni, 2011). In Finland the number of multilingual students with Finnish as an additional language is increasing, especially in the areas with a dense multiethnic population (Statistics Finland, 2019a). Monolingual practices are still prevalent in Finnish basic education, and the shift to understanding multilingual realities is needed (Alisaari et al., 2019; Latomaa \& Suni, 2011). Teachers have not received enough training on working in multilingual contexts (Alisaari et al., 2019; Baker, 2007).

A study carried out by Arnot et al. (2014) noted three key elements that have to be taken into account in EAL education, both in primary and secondary schools: educational achievement, language development, and school integration. Educational achievement refers to a student's academic progress throughout basic education, and it is measured by classroom participation, examinations, and project work. Language development refers to the linguistic skills in a language that is new to the EAL student and as a mediating tool for the learning of different subjects. School integration refers to participation, both academically and socially, emphasizing collaboration and cohesion as means of preventing marginalization and polarization (Arnot et al., 2014).

In sum, as the Finnish basic education system was created in times of relatively strong monolingualism-in spite of the country's official bilingualismchanges in the society now call for an educational update in which the different dimensions (Arnot et al., 2014) are taken into account. Until now, the studies concerning FLLs in Finland have mainly focused on language learning, not on school integration and academic development (Sinkkonen \& Kyttälä, 2014).

\section{Methodology and Data}

Using a qualitative approach, in this study we surveyed teachers' views on a topic that is multi-faceted, sensitive, and relatively new in the Finnish context. According to Creswell (2005), qualitative research is often used to study phenomena that are less examined and when there is a recognized need for listening to the views of the participants of the study (e.g., lanes, Cappello, \& Demo, 2017).

The data for this study were collected using an electronic questionnaire with open-ended questions that was sent to the principals of eight lower secondary schools in northern, eastern, western, central, and southern parts of Finland in October 2016. The reason for sending the questionnaire to schools in different parts of Finland was to find out differences between geographically distant schools. The principals, who were also asked to participate as respondents, forwarded the questionnaires to their teaching staff members.

The survey was developed using the three dimensions of Arnot et. al (2014) as a basis, as we were interested in finding out how teachers reflect on educational achievement, language development, and social integration among FLLs. The 
survey was pre-tested by two special education teachers, and some amendments were made based on their comments in autumn 2016.

The entire research process was conducted in accordance with the guidelines provided by the Finnish National Board on Research Integrity (TENK) (TENK, 2019): Participation was voluntary, and anonymity was guaranteed throughout the process. Reminders asking the respondents to fill out the questionnaires were sent twice to the principals of the schools. By the end of March 2017, the total number of filled questionnaires was 43 , but four questionnaires had to be discarded because of their ambiguity.

Four of the eight schools that were located in the same city in Central Finland have a specific resource of a teacher in linguistic support (TLS) for students after the year of preparatory education. Additional linguistic support is targeted at teaching the language of schooling, Finnish in this case, along with the subject contents (see sheltered English [Baker, 2007]). The school in northern Finland has an additional teacher resource for linguistic support. The schools located in southern, western, and eastern Finland do not have additional teacher resource for linguistic support, but they provide the FLLs with FSL instruction and special education, if needed.

In addition to background information (gender, age, working location, current position, education and main subject, and whether or not teachers had completed their pedagogical studies) the questionnaire had seven statements, some of which gave respondents additional instructions for commenting and giving more information on their choices. The statements used for this study are based on the three dimensions of supporting the language learner at school (see Arnot et al., 2014): educational achievement (Statements 1 and 2), language development (Statements 3, 5, and 6), and school integration (Statement 7). The last, open-ended question was provided for additional opinions and comments. Before commenting in the statements, the teachers were asked first to respond using a five-point scale: 1 (very well), 2 (rather well), 3 (I don't know), 4 (rather poorly), and 5 (very poorly). In addition, they were asked to give reasons for their answers concerning every statement. In this article, we focus on analyzing the comments that the respondents provided for their numerical choices.

The respondents were asked how well they think they know their FLLs and their backgrounds, especially the students who have lived in Finland for five years or less. They were also asked to evaluate the teaching arrangements in their schools. The first two statements are considered within the dimension of educational achievement. The second dimension, language development, is examined with the comments for three questions: (3) What kind of linguistic support is offered at the school? (5) What is the meaning of linguistic support? and (6) What is the role of linguistic support in learning subject-specific contents? For the third dimension, in Statement 7 the respondents were asked to give their opinion on the role of the school in meeting the needs of the students in social integration. 
The data include answers from 39 respondents. Most of them $(n=25,64$ $\%$ are from four schools located in one city in central Finland. The rest of the answers $(n=14,36 \%)$ are from four schools in different parts of Finland. In Figure 1 the division of the respondents and the subjects they teach is presented.

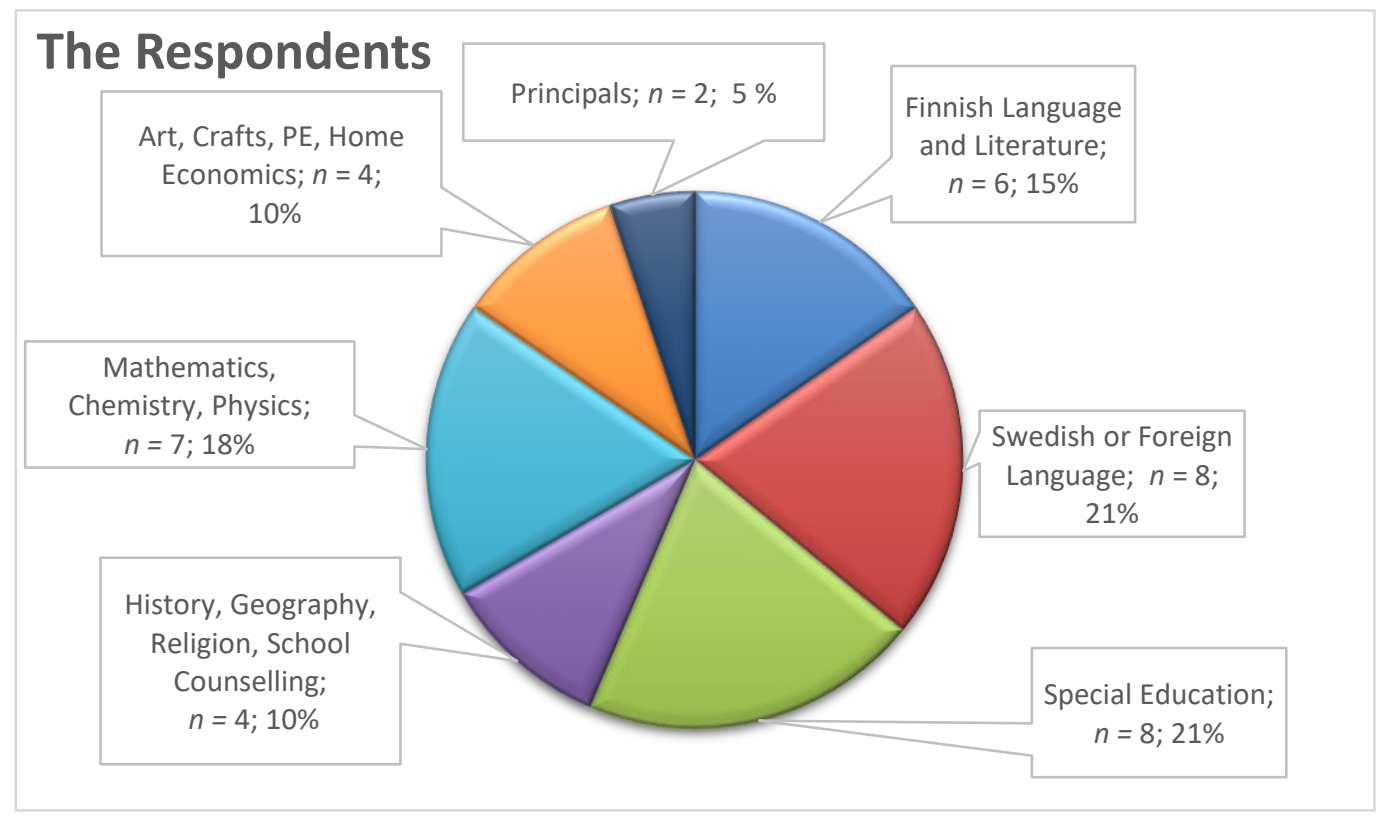

Figure 1. The Respondents and the Subjects They Teach

Altogether, the answers of 39 respondents are analyzed in this study by means of qualitative data analysis (see Miles \& Huberman, 2002). The method of analysis was conventional content analysis (Hsieh \& Shannon, 2005; Patton, 2002), in which the themes were derived from a pre-existing theoretical model presented by Arnot et al. (2014). The comments were categorized for analysis according to the three research questions. The analysis was conducted by the first author.

The quotes from the respondents are represented in random order to anonymize them and coded with "T" for teacher and the ordinal number of the filled questionnaire, followed by the subject the respondent teaches. The quotes were translated from Finnish into English by the first author. The results are represented according to the three dimensions of supporting the language learner at school presented by Arnot et al. (2014).

\section{Results}

The results are given in the order of the research questions. First, the comments concerning knowing the FLLs' backgrounds are presented. Second, the needs of the FLLs for academic support are presented, and third, the needs for linguistic support are reported. 


\section{Knowing the FLLs' Backgrounds}

The respondents reported knowing the backgrounds of their students (i.e., the country of origin, the languages they speak, their skills in Finnish) either rather poorly $(19,49 \%)$ or very poorly $(2,5 \%)$ :

It takes time to know the languages the students speak or their skills in Finnish. One has to be very sensitive about students' backgrounds. Social workers and tutors exercise professional secrecy. I draw my own conclusions if necessary. (T1, FSL)

The students join my classes without me getting any information about their previous situation. They can have had a rough history so asking questions seems inappropriate. (T4, physical education)

I don't know that much. On the other hand, some of the information may be classified as confidential. I would like to get more information on the students' skills in Finnish language. (T21, special education)

The quotes from $\mathrm{T} 1, \mathrm{~T} 4$, and $\mathrm{T} 21$ seem to indicate that teachers are not fully aware of the information that they are supposed to know or of what they are not allowed to know. According to Lucas and Villegas (2013), linguistically responsive teachers possess a repertoire of strategies for learning about the linguistic and academic backgrounds of the language learners in both the language of schooling and their native languages. A linguistically responsive teacher also has to be able to identify the language demands of the classroom tasks (Lucas \& Villegas, 2013), which helps the teacher in supporting the students on their individual ZPDs.

The teachers felt they need to take the initiative in getting information concerning immigrant students:

Mainly it's about me asking the students about their backgrounds. Some of the information can be read in the personal education plan. (T1, FSL)

I know if the student studies Finnish as a second language, nothing more. (T5, history)

I have never received any information on the backgrounds of the immigrant students beforehand. I have collected data after the student has joined my group. (T37, FSL)

As T1, T5, and T37 pointed out, there is no uniform way of providing information for teachers, and teachers often have to do some extra work in order to find out 
where the students are from and what their skills in Finnish are, as well as what their skills in the particular subject in question are.

Furthermore, the homeroom teachers need to know more about their students than does a subject teacher without the responsibility of supervising the class:

I am not very aware of the students' backgrounds. However, I am a homeroom teacher, and I know the students in my own class quite well. (T10, mathematics)

Homeroom teachers are responsible for all the personal education plans in the class, and that can be a reason for knowing the students better than other subject teachers. However, a homeroom class usually consists of 20 to 30 students, whereas the subject teacher supervising the class may teach up to 200 students in a school.

Knowing the student seems to be a core issue for many of the respondents. Of course, it is easier to find out the student's skills when the language spoken is mutual. Many of the respondents pointed out that it is important to know the backgrounds of the students in order to be able to communicate, support, and evaluate the students (see Arnot et al., 2014).

Only one respondent, a special education teacher, reported knowing the new students very well. Three respondents, all teachers of languages, were not able to say. However, 15 teachers said they knew the backgrounds of their students rather well; these teachers were either teachers of a language, especially $\mathrm{FSL}$, or teachers of special education.

\section{The Needs Concerning Academic Support}

The respondents were asked to evaluate the arrangements for academic support (i.e., lesson plan structure, FSL instruction, additional linguistic support, remedial teaching) in the school where they worked. Of the 39 respondents, 30 $(77 \%)$ were of the opinion that the arrangements were organized rather well. However, the respondents pointed out the need for smaller teaching groups and more teacher resources:

We cope with the existing resources the best way we can. However, a lot should be done in order to improve the situation. The sizes of the groups should be small enough for the teacher to pay attention to FLL support. It would also be necessary to limit the number of FLLs per class and avoid placing them all in one group. (T3, languages)

Well, we are trying to support the FLLs, but due to the scarce resources, it is quite impossible. If you are responsible for teaching a subject that needs a lot of reading to be understood by a group of 27 students, it is sometimes 
difficult to estimate the FLLs' needs, both in terms of learning the language and the contents of the subject. (T5, FSL)

There are no guidelines nor equal financial resources for organizing support for immigrant students in Finnish basic education. Furthermore, the respondents seem to have several ideas about how to improve the current situation, such as smaller groups, providing more teachers, and restructuring lesson plans. Many of the respondents stated that with smaller groups, it would be easier to get to know the students, provide them with adequate assistance, and scaffold them (see van Lier, 2004; Walqui, 2006). Good practices need to be developed, and teachers feel they need time for planning and implementing educational methods that meet the needs of more heterogeneous groups (see Sinkkonen \& Kyttälä, 2014).

Three of the respondents considered that the teaching arrangements were carried out very well in their school:

FLLs receive a lot of support, and teachers pay attention to them. For instance, arrangements for taking exams are taken care of well. (T10, mathematics)

Furthermore, T10, a teacher of mathematics, is the only respondent who gave more detailed information on the "very well" organized school arrangements (as quoted), but no further details on the actual means of supporting FLLs are reported by T10.

In sum, the statements concerning school arrangements are quite similar to one another, independent of the fact that the respondents have chosen either rather well $(77 \%)$ or rather poorly $(13 \%)$. Not one of the respondents was of the opinion that school arrangements were organized very poorly. However, all the respondents who had chosen the alternative rather poorly were teachers of languages, who are educated to be aware of issues concerning linguistic development (Kantelinen, Jeskanen \& Koskela, 2016).

\section{The Needs Concerning Linguistic Support}

The majority of the respondents (27,70\%) stated that the arrangements for linguistic support in their schools are organized rather well. However, lack of time and teachers is mentioned by 22 respondents. The similarities in schools are mostly within the availability of FSL instruction and special education. Yet, there are significant differences in offering additional linguistic support (in addition to FSL instruction) and students' mother tongue instruction:

The lack of a clear structure is a problem. Teachers in special education have to use their resources for FLLs, which makes it difficult to provide support for the Finnish-speaking students with special needs. Many subject 
teachers have a lot of knowledge and skills to support FLLs, but it takes a lot of effort. (T1, FSL)

The need for support has been noted, and we do talk about it. Having adequate resources for offering support annually is another story though. (T5, history)

FLLs do get FSL instruction, but there should be more linguistic support in other subjects as well. (T6, FSL)

The lack of a clear structure of support in the schools is referred to by several respondents. The need for linguistic support in all subjects is mentioned in many answers, and it is especially pointed out not just by the teachers specialized in language education or special education but also in the answers of principals and teachers of the other four categories. Although the need for linguistic support is mentioned by other than language teachers and special education teachers, only one of the respondents mentioned the class subject, religion in this case, as a means to also teach the language of schooling. Furthermore, using the students' mother tongues in learning was not mentioned by any of the respondents, which in turn underlines the monolingual ideologies (see Alisaari et al., 2019).

In schools that provide a specific resource in linguistic support (TLS) it was seen as useful help for FLLs by the respondents. In schools with no specific linguistic support other than FSL instruction, organizing linguistic support in other subjects seems to be more challenging:

Our FSL teachers are competent, but there are so few of them that we can't get any help from them concerning the other school subjects. (T28, mathematics)

The comment by T28 is somewhat puzzling, since it is difficult to know who the we is that is referred to: the FLLs or the teachers of other subjects? On the other hand, as pointed out by T40 (religion), it is necessary for all the teachers to support all students' linguistic development. Furthermore, T16 (languages) brings up the challenges in all subjects taught at the lower secondary level: As the teaching is conducted in Finnish and as all the material is in Finnish, mastering the language of schooling - as well as offering support in learning the languageis essential.

Linguistic support or collaboration provided by the teachers of FLLs' mother tongues is mentioned by three respondents, but as T12 (mathematics) states, the teachers of mother tongues teach in several schools, and therefore they do not easily become part of the school community. Further, mother tongue instruction is not available in all municipalities. As the teachers of students' mother tongues are mostly teachers who are not educated in Finland, different working cultures may hinder collaboration with native teachers.

To conclude, we found that the respondents recognized the needs for linguistic support, but they were uncertain about the means to provide it. The 
respondents from different parts of Finland shared similar thoughts concerning the lack of teacher resources as well as large teaching groups, and also the feeling of not knowing how the responsibility of teaching the language of schooling can—or should—be shared among colleagues.

\section{The Needs Concerning Support for Social Integration}

School plays an important role in social integration for every student, and for an FLL, school can be the only place in which to communicate with Finnish peers. Social integration refers to academic and social participation in all school activities (Arnot et al., 2014). All the respondents were of the opinion that in social integration, school is either a very significant place for an FLL (31 respondents, 80 $\%$ ) or a rather significant place for an FLL (8 respondents, $20 \%$ ):

School can be the only place for FLLs to communicate with other people outside their home. (T8, languages, preparatory education)

However, social integration can be problematic in schools in cases where the FLL remains in groups who speak the same (foreign) language:

School, and especially friends alongside with the family, forms the most important basis for integration in society. This should be noted in the schools. FLLs mainly get social contacts within the groups of FLLs, and this should be changed so that FLLs and Finnish-speaking students would communicate more with each other. This would definitely help learning the Finnish language as well. (T15, special education)

Finnish-speaking friends are especially important for FLLs in regard to learning the language. School is the place to make friends and get acquainted with the Finnish habits and traditions. (T31, FSL)

Attention should be paid that the FLLs do not isolate themselves and that they are not isolated from the school community. (T37, FSL)

FLLs are often left on their own and are not included in the groups. (T44, special education)

Language is a tool of both exclusion and inclusion, and therefore it is important to pay attention to social relationships among the FLL and non-FLL students both in classroom strategies as well as in other school activities (Arnot et al., 2014). Moreover, the language used among peers differs from the language that is used for learning the contents of school subjects (see Baker, 2007; Walqui, 2006), and that may not always be recognized by all teachers. Further, providing the FLL with knowledgeable partners for learning the language in social interaction in the classroom (see Donato, 1994; van Lier, 2004) often depends on the pedagogical methods chosen by the teacher. Social integration is seen as a means against exclusion, marginalization, and polarization but how, and to what extend it can be supported in schools remains unclear (see Arnot et al., 2014). 


\section{Discussion and Conclusions}

This study has features that concern both education and linguistics. Furthermore, this study underlines the need for improving the Finnish education system in order to meet the needs of FLLs. Special attention should be paid to create understanding of how improved language development, educational achievement, and social integration reduce the social and academic disadvantage of FLLs (see Arnot et al., 2014).

The understanding of the need to reorganize teaching in multiethnic schools is stated quite clearly, but the lack of concrete action plans is obvious according to the respondents of this study (seeSinclair \& Lau, 2018). Cultural diversity in Finnish classrooms has grown immensely during the past few years, and the means for providing support for both Finnish-speaking students and FLLs are at the development stage. The respondents were clearly aware of the needs that FLLs have, but they also recognized the shortage of financial resources: One teacher in a group of 25 students with several different mother tongues and different kinds of previous school histories provides a challenging environment for both learning and teaching, and scaffolding every student is both time-taking and burdensome. Considering the aspects of pedagogical scaffolding (e.g., Kayi-Aydar, 2013; van Lier, 2004), good practices, especially in heterogeneous classrooms, can be demanding. The problem of not knowing the students' backgrounds is evident as our results revealed that the teachers of subjects other than languages or special education did not have enough information concerning the FLLs they teach. This is consistent with the findings of Latomaa and Suni (2011); over half of the respondents in their study were of the opinion that they did not have enough information on their students' language background.

Furthermore, FSL teachers who work with the students in the field of language learning in particular reported knowing their students either rather well or very well. This may be a result of teaching FSL in relatively small groups (National Audit Office of Finland, 2015). FSL teachers are specifically educated to focus on linguistic development, but language plays a significant role in all subjects. When assessing the students, it is very important to know the students' skills, both in the subject being studied and in the language of schooling, in order to provide equal opportunities to show what the student knows about the topic in question. This, however, is not an easy task since subject teachers in Finland are not comprehensively trained to understand the role of language and literacy in disciplinary learning, nor are they trained in linguistically and culturally responsive pedagogy (Aalto \& Tarnanen, 2017; Kimanen, Alisaari, \& Kallioniemi, 2019). Furthermore, teachers need to become involved in professional growth for developing their expertise in teaching more versatile classes (Alisaari et al., 2019; Kayi-Aydar, 2013; Walqui, 2006). Understanding every teacher's ability to support second language acquisition in all the categories of school languages (Beacco et al., 2015) in order to help the FLLs to progress from basic interpersonal 
communication skills to cognitive academic language proficiency (Cummins, 1981; 2008) is essential.

In order to offer every student, both Finnish-speaking and FLL, experiences of learning in the ZPD, teachers should have enough time to get to know the students as individuals. The results of our study reveal that in order to offer adequate support for students, attention should be paid to financial resources. For instance, co-teaching can only be arranged if there are enough teachers (see Loertscher \& Koechlin, 2015; Saloviita, 2018). However, it is not merely about the financial resources. Many of the respondents pointed out the need for linguistic support in all the subjects, and from a linguistically responsive point of view, every teacher should be able to provide linguistic support in order to enhance both academic and linguistic achievement (Lucas \& Villegas, 2013; Walqui, 2006). This, however, would require a shared understanding that all languages are resources for learning, and that both native learners and FLLs would benefit from a space where all languages are valued (Alisaari et al., 2019; Arnot et al., 2014).

The comments of the respondents show that teachers are aware of the linguistic and academic challenges, but the means to deal with them are ambiguous (see Arnot et al., 2014). Moreover, the issue needs to be discussed by educational organizers in order to attain uniformity and equality in basic education. Local arrangements without coherent guidelines add up to inequality in Finnish basic education, and FLLs have different educational experiences depending on where they live (see Arnot et al., 2014; Sinclair \& Lau, 2018). Many of the respondents pointed out that the importance of the Finnish education system in integrating the students is indisputable, but at the same time, there are many details that have to be improved in order to offer equal education for all. This result is consistent with the findings of Latomaa and Suni (2011).

One of the limitations concerning this study is the small number of respondents. Most of the respondents are either language teachers or special education teachers; however, that can be understood as a result of these teachers being more interested in this topic. The more experience the teachers have teaching students with an immigrant background, the more they see the importance of it and are willing to talk about it. Another limitation of our study is the lack of definition of our sample. We do not know the number of teachers to whom the questionnaire was forwarded by the principals. This makes our data vulnerable to sample bias; as e-questionnaires are quite an efficient tool for data collecting, there is always a risk of the loss of some amount of control (Sargis, Skitka, \& McKeever, 2013). The respondents working in the four schools located in the same city with a specific resource for linguistic support (TLS) shared similar problems with the 14 respondents from other school around Finland. This implies that in spite of the resources provided, the structure of organizing support in teaching remains unclear. Further interviewing of the respondents could have given more information on this topic.

The aim of this study was to let professional teachers reflect on their thoughts concerning FLLs and how the needs of the language learners in the 
classrooms are met. The value of this research is that it reveals the need for improvements in the Finnish school context from the teachers' point of view. Finnish basic education, as well as Finnish society, is undergoing significant changes. Cultural diversity and linguistic challenges are a growing part of our education system. As the classrooms grow more diverse, this study indicates that pre-service and in-service teacher education also have to be developed: Teaching the language of schooling is not for language teachers only.

\section{Practical Implications}

Finland is known for high quality education, but further development of the Finnish education system is required in order to maintain the quality of education. The Finnish National Core Curriculum for Basic Education (FNAE, 2014) states that every teacher is a language teacher. However, teachers of subjects other than languages have not received training as language teachers. Diversity in Education (DivEd; DivEd, 2019), a key government project, is one of the current projects developing both pre-service and in-service teacher education towards linguistically and culturally responsive methods in Finland. Unfortunately, a project with a limited time of funding is not able to reach the whole country, nor all the teachers.

Although it is very important to include linguistically and culturally responsive pedagogy in all teacher education, reconsidering the Finnish teachers' job descriptions is required. The results of this study indicate that when schools have a specific linguistic support (a TLS), teachers of other subjects also recognize its importance in supporting the FLLs. Unfortunately, special education teachers, who have not received any particular training in a specific linguistic approach, often teach FLLs who would benefit from teaching strategies aimed at learning both the content and the language. Given the growing student diversity, the teaching staff needs to have new members. In addition to subject teachers and special education teachers, we need teachers who are specifically trained in offering linguistic support (i.e., TLSs) in collaboration with other teachers, for example, teachers trained in co-teaching, in collaborating in lesson planning, and in providing opportunities for creating smaller teaching groups (Harju-Autti et al., 2018).

The findings of this study are applicable in all countries in which English is not an official language: That means all the Nordic countries but also other countries around the world. As the linguistic landscape has changed, the education system cannot remain the same. Lucas and Villegas (2013) emphasized the value of linguistic diversity in schools: A linguistically responsive teacher sees that linguistic diversity is worth cultivating, which in turn requires sociolinguistic skills from all teachers. However, teacher education does not necessarily provide its students with adequate skills in sociolinguistics nor in linguistically and culturally responsive pedagogy. Development of both teacher education programs and the job descriptions concerning these teachers is required to meet the needs of linguistically and culturally diverse classrooms. 


\section{References}

Aalto, E., \& Tarnanen, M. (2017). Negotiating language across disciplines in preservice teacher collaboration. European Journal of Applied Linguistics, 5(2), 245-271. doi:10.1515/eujal-2017-0011

Alisaari, J., Heikkola, L. M., Commins, N., \& Acquah, E. O. (2019). Monolingual ideologies confronting multilingual realities: Finnish teachers' beliefs about linguistic diversity. Teaching and Teacher Education, 80, 48-58.

Arnot, M., Schneider, C., Evans, M., Liu, Y., Welply, O., \& Davies-Tutt, D. (2014). School approaches to the education of EAL students: Language development, social integration and achievement. Cambridge; UK: The Bell Foundation. Retrieved from https://www.educ.cam.ac.uk/research/projects/ealead/Fullreport.pdf

Baker, C. (2007). A parents' and teachers' guide to bilingualism ( $3^{\text {rd }}$ ed.). Clevedon, UK: Multilingual Matters.

Basic Education Act 628/1998. (1998). Ministry of Culture and Education. Ministry of Culture and Education, Finland, Finlex. Retrieved from https://www.finlex.fi/fi/laki/kaannokset/1998/en19980628.pdf

Beacco, J. C., Fleming, M., Gouller, F., Thürmann, E., \& Vollmer, H. (2015). The language dimension in all subjects: The handbook for curriculum development and teacher training. Strasbourg, France: Council of Europe: Language Policy Unit.

Breidbach, S., Elsner, D. \& Young, A. (eds). (2011). Language awareness in teacher education: Cultural-political and social-educational perspectives. Frankfurt am Main: Peter Lang.

Carter R. (2003). Language awareness. ELT Journal, 57(1), 64-65. Retrieved from

doi:http://search.ebscohost.com/login.aspx?direct=true\&AuthType=cookie, ip, $u$ id \&db=mlf\&AN=2003650271\&site=ehost-live\&scope =site

Cenoz, J., \& Gorter, D. (2019) Multilingualism, translanguaging, and minority languages in SLA. The Modern Language Journal, 103, 130-135. doi: $10.1111 /$ modl. 12529

City of Helsinki (2019). Introduction to schools. Guide to comprehensive education in Helsinki. Retrieved from https://www.hel.fi/static/liitteet/opev/mauna/introduction-to-schools.pdf

Civitillo, S., Schachner, M., Juang, L., van der Vijver, F. J. R., Handrick, A., \& Noack, P. (2016). Towards a better understanding of cultural diversity approaches at school: A multi-informant and mixed-methods study. 
Learning, Culture and Social Interaction, 12, 1-14.

https://doi.org/10.1016/j.lcsi.2016.09.002

Creswell, J. W. (2005). Educational research: Planning, conducting, and evaluating quantitative and qualitative research. Upper Saddle River, NJ: Pearson Merrill Prentice Hall.

Cummins, J. (1981). Bilingualism and minority-language children. Language and Literacy Series. Toronto, Canada: Ontario Institute for Studies in Education.

Cummins, J. (2008). Reading and the ESL student. Orbit, 37, 72-75. Retrieved from

https://libproxy.tuni.fi/login?url=https://search.proquest.com/docview/2137 33753 ? accountid $=14242$

Denham, K., \& Lobeck, A. (Eds.) (2010). Linguistics at school: Language awareness in primary and secondary education. Cambridge, UK: Cambridge University Press.

Dervin, F., \& Liddicoat, A. (2013). Linguistics for intercultural education. Amsterdam, The Netherlands: John Benjamins Publishing Company.

DivEd. (2019). Diversity in education. A government key project. Retrieved from www.dived.fi

Donato, R. (1994). Collective scaffolding in second language learning. In J. P. Lantolf \& G. Appel (Eds.), Vygotskian approaches to second language research (pp. 33-56). Norwood, NJ: Ablex Publishing Corporation.

Finlex. (1998). Asetus opetustoimen henkilöstön kelpoisuusvaatimuksista [The decree on the qualification requirements concerning teaching staff]. Retrieved from https://www.finlex.fi/fi/laki/ajantasa/1998/19980986

Finlex. (2007). Opetusministeriön asetus vieraskielisten sekä saamenkielisten ja romanikielisten oppilaiden täydentävään opetukseen perusopetuksessa ja lukiokoulutuksessa myönnettävän valtionavustuksen perusteista [The decree on funding concerning foreign-language-, Sámi- and Romaspeaking students in comprehensive and secondary education by the Ministry of Education and Culture]. Retrieved from https://www.finlex.fi/fi/laki/alkup/2007/20070392

Finnish National Agency for Education. (2014). National core curriculum for basic education. Helsinki, Finland: Finnish National Agency for Education.

Finnish National Agency for Education. (2015a). Inclusion of migrants is a challenge to the education system. Retrieved from https://www.oph.fi/english/current_issues/101/0/inclusion_of_migrants_is_ a_challenge_to_the_education_system

Finnish National Agency for Education. (2015b). Perusopetukseen valmistavan opetuksen opetussuunnitelman perusteet [National core curriculum for preparatory education]. Retrieved from 
http://www.oph.fi/download/172848_perusopetukseen_valmistavan_opetu ksen_opetussuunnitelman_perusteet_2015.pdf

Finnish National Agency for Education (2019a). Maahanmuuttajataustaisten oppilaiden opetus [Teaching immigrant students]. Retrieved from https://www.oph.fi/koulutus_ja_tutkinnot/perusopetus/kielija_kulttuuriryhmat/maahanmuuttajataustaiset_oppilaat

Finnish National Agency for Education. 2019b. Usein kysyttyä: Perusopetuksen suomi toisena kielenä ja kirjallisuus -oppimäärä [FAQ: The syllabus of Finnish as a second language and literature in basic education]. Retrieved from https://www.oph.fi/koulutus_ja_tutkinnot/perusopetus/kielija_kulttuuriryhmat/maahanmuuttajataustaiset_oppilaat/perusopetuksen_s 2_oppimaara/103/0/onko_perusopetuksen_oppilaitoksilla_velvollisuus_jarj estaa_s2-opetusta

Gutentag, T., Horenczyk, G., \& Tatar, M. (2017). Teachers' approaches toward cultural diversity predict diversity-related burnout and self-efficacy. Journal of Teacher Education, 69, 408-419. doi: 10.1177/0022487117714244

Hachfeld, A., Anders, Y., Schroeder, S., Stanat, P., \& Kunter, M. (2010). Does immigration background matter? How teachers' predictions of students' performance relate to student background. International Journal of Educational Research, 49, 78-91. doi:10.1016/j.ijer.2010.09.002

Harju-Autti, R., Aine, T., Räihä, P., \& Sinkkonen, H-M. (2018). Kielellisesti tuettu opetus (KIETU-opetus) yläkouluikäisten maahanmuuttajaoppilaiden pedagogisena tukena [A teacher of linguistic support (TLS): Scaffolding multilingual adolescents in Finnish basic education). NMI-Bulletin, 2018(3), 16-31.

Harju-Luukkainen, H., Nissinen, K., Sulkunen, S., Suni, M., \& Vettenranta, J. (2014). Avaimet osaamiseen ja tulevaisuuteen. Selvitys maahanmuuttajataustaisten nuorten osaamisesta ja siihen liittyvistä taustatekijöistä PISA 2012-tutkimuksessa [Keys for learning and the future: A report on the immigrant learners in PISA 2012]. Jyväskylä: Jyväskylän yliopisto, Koulutuksen tutkimuslaitos [Jyväskylä: University of Jyväskylä, Finland, The Finnish Institute of Educational Research].

Heino, T., \& Oranen, M. (2012). Lastensuojelun asiakkaiden koulunkäynti erityistäkö? [The customers of child welfare and going to school - special education?] In M. Jahnukainen (Ed.), Lasten erityishuolto ja -opetus Suomessa [Special care and special education for children in Finland] (pp. 217-240). Tampere, Finland: Vastapaino.

Hildén, R., \& Kantelinen, R. (2012). Language education - foreign languages. In H. Niemi, A. Toom, \& A. Kallioniemi (Eds.), Miracle of education (pp. 161176). Rotterdam, the Netherlands: SensePublishers.

Honko, M. (2013). Alakouluikäisten leksikaalinen tieto ja taito: toisen sukupolven suomi ja S1-verrokit [Primary school students' lexical knowledge and 
skills: The Finnish of second-generation migrants compared to native Finnish speakers]. Tampereen yliopisto. Tampere, Finland: Tampere University Press.

Hsieh, H.-F., \& Shannon, S. E. (2005). Three approaches to qualitative content analysis. Qualitative Health Research, 15(9), 1277-1288.

doi:10.1177.1049732305276687

lanes, D., Cappello, S., \& Demo, H. (2017). Teachers and student voices: A comparison between two perspectives to study integration processes in Italy. European Journal of Special Needs Education, 32(3), 301-311.

Kantelinen, R., Jeskanen, S., \& Koskela, T. (2016). Kieltenopettaja kielikasvatuksen ammattilaisena - asiantuntijuus muutoksessa. Kieli, koulutus ja yhteiskunta. [A language teacher as a language education expert - expertise in transition. Language, education and society] 9.3.2016 (March). Retrieved from http://www.kieliverkosto.fi/article/kieltenopettajakielikasvatuksen-ammattilaisena-asiantuntijuus-muutoksessa/

Kayi-Aydar, H. (2013). Scaffolding language learning in an academic ESL classroom. ELT Journal, 67(3), 324-335. doi:10.1093/elt/ccto16

Kimanen, A., Alisaari, J., \& Kallioniemi, A. (2019). In-service and pre-service teachers' orientations to linguistic, cultural and worldview diversity. Journal of Teacher Education and Educators, 8(1), 35-54.

Lantolf, J.P., \& Appel, G. (1994). Theoretical framework: An introduction to Vygotskian perspectives on second language research in speakers. In Vygotskian approaches to second language research (J. P. Lantolf \& G. Appel, Eds.) (pp. 1-32). Norwood, NJ: Ablex Publishing Corporation.

Lantolf, J. P., \& Poehner, M. E. (2010). Dynamic assessment in the classroom: Vygotskian praxis for second language development. Language Teaching Research, 15(1), 11-33. doi:10.1177/1362168810383328

Lantolf, J. P., \& Thorne, S. L. (2006). Sociocultural theory and the genesis of second language development. Oxford, UK: Oxford University Press.

Latomaa, S., \& Suni, M., (2011). Multilingualism in Finnish schools: Principles and practices. Journal of Estonian and Finno-Ugric Linguistics, 2, 111136. Retrieved from http://jeful.ut.ee/public/files/Latomaa\%20and\%20Suni\%20111-136.pdf

Loertscher, D. V., \& Koechlin, C. (2015). Finland, collaboration and co-teaching. Teacher Librarian, 42(3), 56-57.

Lucas, T., \& Villegas, A. M. (2013). Preparing linguistically responsive teachers: Laying the foundation in pre-service teacher education. Theory into Practice, 52(2), 98-109. doi:10.1080/00405841.2013.770327

Martikainen, T. (2013). Religion, migration, settlement: Reflections on post-1990 immigration to Finland. Leiden, the Netherlands: Brill. 
Miles, M. B., \& Huberman, A. M., (Eds.) (2002). The qualitative researcher's companion. Thousand Oaks, CA: Sage Publications. doi:10.4135/9781412986274

Ministry of Culture and Education. (2019.) Basic education. Retrieved from https://minedu.fi/en/basic-education

Morgan, H. (2016). Relying on high-stakes standarized tests to evaluate schools and teachers: A bad idea. The Clearing House, 89(2), 67-72. doi:10.1080.00098655.2016.1156628

National Audit Office of Finland. (2015). Immigrant students and the effectiveness of basic education. Retrieved from https://www.vtv.fi/en/publications/immigrant-students-and-theeffectiveness-of-basic-education/

Niemi, H., Toom, A., \& Kallioniemi, A. (2012). Miracle of education: The principles and practices of teaching and learning in Finnish schools. Rotterdam, the Netherlands: Sense Publishers.

Organisation for Economic Co-operation and Development. (2015). Immigrant students at school. Easing the journey towards integration. OECD Publishing. Retrieved from https://read.oecdilibrary.org/education/immigrant-students-at-school 9789264249509 en\#page1

Patton, M. Q. (2002). Qualitative research and evaluation methods. Thousand Oaks, CA: Sage.

Saloviita, T. (2018). How common are inclusive educational practices among Finnish teachers? International Journal of Inclusive Education, 22(5), 560575. doi:10.1080/13603116.2017.1390001

Sargis, E. G., Skitka, L. J., \& McKeever, W. (2013). The internet as psychological laboratory revisited: Best practices, challenges, and solutions. In $Y$. Amichai-Hamburger (Ed.), The social net: Understanding our online behavior. Oxford, UK: Oxford University Press.

Sinclair, J., \& Lau, C. (2018). Initial assessment for K-12 English language support in six countries: Revisiting the validity-reliability paradox. Language and Education, 32(3), 257-285. doi:10.1080/09500782.2018.1430825

Sinkkonen, H.-M., \& Kyttälä, M. (2014). Experiences of Finnish teachers working with immigrant students. European Journal of Special Needs Education, 29(2), 167-183. doi:10.1080/08856257.2014.891719

Spolsky, B. (2008). Introduction: What is educational linguistics? In B. Spolsky \& F. M. Hult (Eds.), The handbook of educational linguistics (pp. 1-9). Malden, MA: Blackwell.

Statistics Finland. (2019a). Immigrants settle in the cities, but also in the rural areas. Retrieved from 
https://www.stat.fi/tietotrendit/artikkelit/2019/maahanmuuttajat-suuntaavatkaupunkeihin-euroopasta-tulleita-asettunut-maaseudullekin/

Statistics Finland. (2019b). Foreign-language speakers. Retreived from https://www.stat.fi/tup/maahanmuutto/maahanmuuttajatvaestossa/vieraskieliset en.html\#tab14839723139842

Suni, M., \& Latomaa, S. (2012). Dealing with increasing linguistic diversity in schools - the Finnish example. In J. Blommaert, S. Leppänen, P. Pahta, \& T. Räisänen (Eds.), Dangerous multilingualism: Northern perspectives to order, purity and normality (pp. 67-95). Basingstoke, UK: Palgrave Macmillan.

Talib, M-T. (2002). Monikulttuurinen koulu, haaste ja mahdollisuus [The multicultural school: Both a challenge and a possibility]. Helsinki, Finland: Kirjapaja.

TENK. Finnish National Board on Research Integrity. (2019). Responsible conduct of research. Retrieved from https://www.tenk.fi/en/responsibleconduct-of-research

van den Broek, E. W. R., Oolbekkink-Marchand, H. W., Unsworth, S., van Kemenande, A. M. C, \& Meijer, P.C. (2019). Unravelling upper-secondary school teachers' beliefs about language awareness: From conflicts to challenges in the EFL context. Language Awareness, 27(4), 331-353 doi:10.1080/09658416.2018.1523910

van Lier, L. (2004). The ecology and semiotics of language learning: A sociocultural perspective. Dordrecht, the Netherlands: Kluwer Academic Publishers.

Vettenranta, J., Välijärvi, J., Ahonen, A., Hautamäki, J. Hiltunen, J., Leino, K., Lähteinen, S., Nissinen, K., Nissinen, V., Puhakka, E., Rautopuro, J., \& Vainikainen, M.-P. (2016). Pisa 15 Ensituloksia. Huipulla pudotuksesta huolimatta [PISA 15 Initial results: On top in spite of a slight drop]. Opetusja kulttuuriministeriön julkaisuja 2016:41. Retrieved from http://julkaisut.valtioneuvosto.fi/bitstream/handle/10024/79052/okm41.pdf

Vygotsky, L. S. (1978). Mind in society: The development of higher psychological processes. Cambridge, MA: Harvard University Press.

Vygotsky, L. S. (1986). Thought and language. Cambridge, MA: M.I.T. Press.

Walqui, A. (2006). Scaffolding instruction for English language learners: A conceptual framework. International Journal of Bilingual Education and Bilingualism, 9(2), 159-180.

Washburn, G. N. (1994). Working in the ZPD: Fossilized and nonfossilized nonnative speakers. In J. P. Lantolf \& G. Appel (Eds.), Vygotskian approaches to second language (pp. 67-81). Norwood, NJ: Ablex Publishing. 
Wood, D., Bruner, J. S., \& Ross, G. (1976). The role of tutoring in problem solving. Child Psychology \& Psychiatry \& Allied Disciplines, 17(2), 89-100.

Zuengler, J., \& Miller, E. R. (2006). Cognitive and sociocultural perspectives: Two parallel SLA worlds? TESOL Quarterly, 40(1), 35-58.

\section{Author Contact}

Raisa Harju-Autti, raisa.harju-autti@tuni.fi MA, Doctoral Researcher, University Instructor

Faculty of Education and Culture, Åkerlundinkatu 5, 33014 Tampere University

Hanna-Maija Sinkkonen, hanna-maija.sinkkonen@utu.fi

University of Turku

$\mathrm{PhD}$ (Education Sciences) Docent (Special Education) 